\title{
ASPEK HUKUM DALAM PENYELENGGARAAN PRAKTIK KEDOKTERAN DIHUBUNGKAN DENGAN UNDANG-UNDANG NOMOR 29 TAHUN 2004 TENTANG PRAKTIK KEDOKTERAN
}

\author{
Oleh: Hj. Ukilah Supriyatin, S.H., M.H. ${ }^{*}$
}

\begin{abstract}
Society is not only an object but also the subject of health implementation, therefore the implementation of public health service is a joint responsibility between the government and the community. public policy with Law Number 29 Year 2004 regarding Medical Practice, is expected to overcome the problems related to the implementation of the drafting of the law. The problems underlying the drafting of the law, first is to provide protection for the society against medical practice and not in accordance with medical ethics that resulted in decreased public confidence in the medical profession. Second, provide legal certainty and legal protection for the medical profession of the public lawsuit.
\end{abstract}

Keywords: The Medical Practice Act, Legal aspect

\section{Abstrak}

Masyarakat bukan hanya menjadi objek melainkan juga subjek penyelenggaraan kesehatan, karena itu penyelenggaraan pelayanan kesehatan masyarakat merupakan tanggung jawab bersama antara pemerintah dan masyarakat. kebijakan publik dengan Undang-undang Nomor 29 Tahun 2004 tentang Praktik Kedokteran, diharapkan dapat mengatasi permasalahan yang berhubungan dengan penyelenggaraan penyusunan undang-undang tersebut. Permasalahan yang mendasari penyusunan undang-undang tersebut, pertama adalah memberikan perlindungan bagi masyarakat terhadap praktik kedokteran dan tidak sesuai dengan etika kedokteran sehingga mengakibatkan penurunan kepercayaan masyarakat terhadap profesi medik. Kedua, memberikan kepastian hukum dan perlindungan hukum bagi profesi dokter dari gugatan masyarakat.

Kata Kunci: Undang-undang Praktik Kedokteran, Aspek hukumnya

\section{Pendahuluan}

Undang-Undang Republik Indonesia Nomor 29 Tahun 2004 tentang Praktik Kedokteran sering (selanjutnya disingkat UUPK) dianggap sebagai (sama dengan) hukum kedokteran atau juga sebagai hukum kesehatan. Pandangan tersebut

\footnotetext{
* Dosen Fakultas Hukum Universitas Galuh
} 
terjadi bila hukum dimaknai sebagai peraturan untuk memenuhi kebutuhan praktis yaitu untuk menyelesaikan permasalahan yang dihadapi masyarakat dalam hubungannya dengan tenaga kesehatan yang inti permasalahannya berhubungan dengan penyelengaraan praktik kedokteran. Peraturan perundangan merupakan salah satu wujud hukum, sementara hukum sendiri mengandung pengertian yang lebih luas daripada wujud tersebut, sekalipun segala hal telah ditata memenuhi ukuran perundang-undangan yang baik di dalam praktiknya, masih terdapat berbagai kekurangan sehingga diperlukan pemahaman yang memadai.

\section{Pembahasan}

Hukum kesehatan meliputi ketentuan yang secara langsung mengatur masalah kesehatan, penerapan ketentuan hukum pidana, hukum perdata, dan hukum administrasi yang berhubungan dengan masalah kesehatan.

Hukum kedokteran meliputi ruang lingkup:

1. Peraturan perundang-undangan yang secara langsung dan tidak langsung masalah bidang kedokteran; contohnya, Undang-undang Nomor 29 Tahun 2004;

2. Penerapan ketentuan hukum administrasi, hukum perdata, dan hukum pidana yang tepat untuk hal tersebut;

3. Kebiasaan yang baik dan diikuti secara terus menerus dalam bidang kedokteran, perjanjian serta perkembangan ilmu pengetahuan praktik kedokteran menjadi sumber hukum dalam bidang kedokteran;

4. Putusan hakim yang telah mempunyai kekuatan hukum tetap, menjadi sumber hukum dalam bidang kedokteran.

Uraian di atas menunjukkan bahwa UUPK hanya salah satu aspek hukum yang berhubungan dengan penyelenggaraan praktik kedokteran.

a. Undang-Undang Republik Indonesai Nomor 29 Tahun 2004 tentang Praktik Kedokteran

Pengaturan penyelenggaraan praktik kedokteran berlandaskan pada asas kenegaraan, keilmuan, kemanfaatan, kemanusiaan, dan keadilan.

Keberadaan Undang-undang Nomor 29 Tahun 2004 tentang praktik kedokteran dimaksudkan untuk:

1. Memberikan perlindungan kepada pasien; 
2. Mempertahankan dan meningkatkan mutu pelayanan medis yang diberikan oleh dokter dan dokter gigi;

3. Memberikan kepastian hukum kepada masyarakat, dokter, dan dokter gigi.

\section{b. Aspek hukum administrasi dalam penyelenggaraan praktik kedokteran}

Setiap dokter/ dokter gigi yang telah menyelesaikan pendidikan dan ingin menjalankan praktik kedokteran harus memiliki izin. Izin menjalankan praktik memiliki 2 makna:

1. Izin dalam arti memberikan kewenangan secara formil;

2. Izin dalam arti pemberian kewenangan secara materil.

Pada hakekatnya izin (formal atau materil) menurut hukum administrasi adalah:

1. Mengarahkan aktivitas, artinya pemberian izin (formal atau materil) dapat memberikan konstribusi ditegakkannya penerapan standar profesi dan standar pelayanan yang harus dipenuhi oleh para dokter/ dokter gigi dalam pelaksanaan praktiknya.

2. Mencegah bahaya yang mungkin timbul dalam rangka penyelenggaraan praktik kedokteran dan mencegah penyelenggaraan praktik kedokteran oleh orang yang tidak berhak.

3. Mendistribusikan tenaga dokter/ dokter gigi yang dihubungkan dengan kewenangan pemerintah daerah atas pembatasan tempat praktik dan penataan Surat Izin Praktik (SIP)

4. Melakukan proses seleksi yakni penilaian administratif, serta kemampuan teknis yang harus dipenuhi oleh setiap dokter/ dokter gigi.

5. Memberikan perlindungan terhadap warga masyarakat terhadap praktik yang tidak dilakukan oleh orang yang memiliki kompetensi tertentu.

Bentuknya izin diberikan dalam bentuk tertulis, berdasarkan permohonan tertulis diajukan lembaga yang berwenang mengeluarkan izin juga didasarkan pada kemampuan untuk melakukan penilaian administratif dan teknis kedokteran.

Pengeluaran izin berlandaskan pada azas-azas keterbukaan, persamanaan hak, ketelitian, keputusan yang baik dan apabila syarat-syarat tersebut tidak dipenuhi, maka izin ditarik kembali 
Telah terjadi beberapa perubahan mendasar yang berhubungan dengan perizinan di dalam UUPK yaitu:

1. Digunakan terminologi Surat Tanda Registrasi (STR) yang diberikan oleh Konsil Kedokteran Indonesia sebagai pengganti terminologi Surat Penugasan (SP) (Pasal 29 (3) Undang-Undang Nomor 29 Tahun 2004);

2. Untuk mendapatkan STR, pertama kali dilakukan uji kompetensi oleh organisasi profesi / dengan sertifikat kompetensi;

3. STR diberikan oleh KKI dan berlaku selama 5 tahun dan dapat diperpanjang melalui uji kompetensi lagi (pasal 29 ayat (4) UndangUndang Nomor 29 Tahun 2004)

4. Masa berlaku SIP sesuai STR, dengan kata lain bilamana berlaku STR habis, maka SIP juga habis (pasal 29 ayat (4) Undang-Undang Nomor 29 Tahun 2004).

\section{c. Aspek hukum perdata dalam penyelenggaraan praktik kedokteran}

Setelah seorang dokter memilki izin untuk praktik, timbul hubungan hukum dalam rangka pelaksanaan praktik kedokteran yang masing-masing pihak (dokter dan pasien) memiliki kebebasan hak dan kewajiban dalam menjalankan komunikasi dan interaksi dua arah.

Hak memberikan perlindungan kepada kedua belah pihak melalui perangkat hukum yang disebut "informed consent". Objek dalam hubungan hukum tersebut adalah pelayanan kesehatan kepada pasien dihubungkan dengan UUPK. Perangkat hukum "informed consent" tersebut diarahkan untuk:

1. Menghormati harkat martabat pasien melalui pemberian informasi dan persetujuan atas tindakan yang akan dilakukan;

2. Meningkatkan kesadaran, kemauan, dan kemampuan hidup sehat;

3. Menumbuhkan sikap positif dan itikad baik serta profesionalisme pada peran dokter dan dokter gigi mengingat pentingnya harkat martabat pasien;

4. Memelihara dan meningkatkan mutu pelayanan sesuai standar dan persyaratan yang berlaku.

Suatu hubungan hukum dianggap sah apabila memenuhi syarat perjanjian. Syarat perjanjian sebagaimana diatur dalam pasal 1320 KUHPerdata: 
1. Kesepakatan, untuk saling mengikatkan diri;

2. Kecakapan, untuk saling memberikan prestasi;

3. Suatu hal tertentu;

4. Suatu sebab yang halal yang diperbolehkan.

Hak individu di bidang kesehatan bersumber pada 2 prinsip yaitu: 1) hak atas pemeliharaan kesehatan; 2) hak untuk menentukan (nasib) sendiri.

Hak yang pertama berorientasi pada nilai sosial dan yang kedua berorientasi pada ciri atau karakteristik individual. Hak dan kewajiban yang timbul dalam hubungan pasien dan dokter meliputi penyampaian informasi dan penentuan tindakan.

1. Pasien wajib memberikan informasi (pasal 53 Undang-undang Nomor 29 Tahun 2004) yang berhubungan dengan keluhan dan menerima informasi pasal 52 Undang-undang Nomor 29 Tahun 2004) (yang cukup dari dokter/ dokter gigi dan pasien berhak mengambil keputusan untuk dirinya sendiri.

2. Dokter berhak mendapat informasi yang cukup dari pasien (pasal 50 Undang-undang Nomor 29 Tahun 2004)

3. Dokter wajib memberikan informasi yang cukup sehubungan dengan kondisi atau akibat yang akan terjadi (pasal 51 Undang-undang Nomor 29 Tahun 2004).

4. Dokter berhak mengusulkan yang terbaik sesuai kemampuan dan penilaian profesionalnya dan berhak menolak bila permintaan pasien dirasa tidak sesuai dengan norma, etika serta kemampuan profesionalnya.

5. Dokter wajib melakukan pencatatan (rekam medik) dengan baik dan benar (pasal 46 Undang-undang Nomor 29 Tahun 2004)

Secara tegas UUPK telah mengatur materi muatan

1) Prinsip keahlian dan kewenangan diwujudkan dalam materi pengaturan bahwasannya dokter harus menjalankan praktik sesuai dengan standar profesi dan merujuk bila kondisi yang terjadi di luar keahlian dan kewenangannya (pasal 51 Undang-undang Nomor 29 Tahun 2004)

2) Prinsip otoritas pasien diwujudkan dengan peraturan bahwasannya setiap tindakan kedokteran/ kedokteran gigi harus mendapat persetujuan. Persetujuan pasien baru dapat diberikan setelah meneria 
informasi dan mentaati segala sesuatu yang menyangkut tindakan tersebut (pasal 45 Undang-undang Nomor 29 Tahun 2004)

3) Prinsip pencatatan (rekam medik) (pasal 46 dan 47 Undang-undang Nomor 29 Tahun 2004)

Dalam hukum acara perdata maupun acara pidana ikenal alat bukti dengan tulisan. Bertolak dari hal tersebut, maka rekam medik sebagai catatan yang dibuat dokter/ dokter gigi dianggap dapat digunakan sebagai alat bukti dengan tulisan rekam medik dapat digunakan sebagai petunjuk pembuktian sepanjang dilakukan dengan cermat sesuai dengan ketetentuan berlaku.

4) Prinsip perlindungan kepada pasien berupa kewajiban dokter menyimpan rahasia pasien yang diketahui baik secara langsung maupun tidak langsung (pasal 47 dan 48 Undang-undang Nomor 29 Tahun 2004)

Rahasia pasien yang diketahui dokter/ dokter gigi dapat diungkap bila:

a) Ada izin dari pasien yang dinyatakan secara tegas/ tidak tegas

b) Didasarkan pada perjanjian pasien, kepada siapa rahasia itu boleh diungkapkan.

c) Kewajiban membuka rahasia didasarkan pada kekuatan suatu undang-undang

d) Pembukaan rahasia atas perintah hakim

e) Inividu yang merupakan public figur

5) Hubungan hukum pada umumnya antara dokter dan pasien

Praktik kedokteran diselenggarakan berdasarkan kesepakatan antara dokter/ dokter gigi dengan pasien dalam upaya untuk pemeliharaan kesehatan, pencegahan penyakit, peningkatan kesehatan, pengobatan penyakit dan pemulihan penyakit. Hal tersebut yakni berdasarkan kesepakatan menunjukkan bahwa hubungan antara dokter dengan pasien tidak ditekankan hasilnya melainkan upaya semaksimal mungkin sesuai dengan standar profesi medik.

6) Aspek perdata lainnya adalah tuntutan ganti rugi berdasarkan perbuatan melanggar hukum (onrechtmatigedaad) (pasal 1365 KUHPerdata)

Beberapa syarat yang harus dipenuhi untuk penerapan aspek ini:

a) Adanya perbuatan (berbuat/ tidak berbuat) 
b) Perbuatan itu melanggar hukum, perundang-undangan, kebiasan dan kesusilaan

c) Ada kerugian

d) Ada hubungan sebab akibat antara perbuatan dengan kerugian

e) Ada unsur kesalahan

Ukuran yang digunakan adalah kesesuaian dengan standar profesi medik. Pengertian di atas menunjukkan bahwa sekalipun hubungan antara dokter dengan pasien adalah upaya semaksimal mungkin, tapi tidak tertutup kemungkinan timbulnya ganti rugi yang didasarkan perbuatan melanggar hukum yang dokter harus mempertanggung jawabkan perbuatan tersebut dari segi hukum perdata.

\section{d. Aspek hukum pidana dalam penyelenggaran praktik kedokteran}

Penataan hukum pidana diperlukan dalam upaya melinungi masyarakat. Hakikat ketentuan pidana adalah meminta pertanggung jawaban melalui tuntutan pidana untuk hal-hal yang telah ditentukan terlebih dahulu.

Dalam KUHPidana disebutkan bahwa dasar penambahan harus dengan undang-undang. Berdasarkan pengertian, tersebut maka beberapa ketentuan pidana yang berhubungan dengan penyelenggaraan praktik kedokteran telah diatur dalam KUHPidana, tetapi masih dibutuhkan beberapa penambahan sesuai dengan kemajuan ilmu pengetahuan dan teknologi, oleh karena itu beberapa perbuatan yang dapat dikenai pidana dicantumkan dalam UUPK.

\section{III.Kesimpulan}

Berdasarkan pembahasan di atas, dapat disimpulkan antara lain:

1. Aspek hukum administrasi dalam penyelenggaraan praktik kedokteran dalam pelaksanaannya masih diperlukan ketentuan-ketentuan lain sebagai upaya untuk memenuhi aspek perlindungan serta aspek administratif:

a. Kewajiban menyusun dan melaksanakan peraturan-peraturan internal rumah sakit

b. Kewajiban melaksanakan audit medik dan audit manajemen secara berkala dan benar pada setiap institusi kesehatan termasuk di dalamnya transparasi pertanggung jawaban publik serta pelaksanaannya berdasarkan bukti. 
2. Aspek hukum perdata dapat memberikan perlindungan hukum terhadap kedua belah pihak (pasien dan dokter) dalam melaksanakan kesehatan, didasarkan atas saling percaya dalam usaha kesedarajatan di antara kedua belah pihak dan aspek perdata lainnya apabila terjadi tuntutan ganti rugi berdasarkan perbuatan melanggar hukum (onrechtmatigedaad) dokter harus dapat mempertanggungjawabkan perbuatannya dari segi hukum perdata.

3. Aspek hukum pidana, di dalam UUPK tidak hanya dilihat dari kepentingan dokter melainkan lebih kepada upaya menciptakan ketertiban terhadap ketentuan yang sudah ada dan memberikan kepastian hukum bagi masyarakat.

\section{Daftar Pustaka}

Ameln, Fred, 1991, Kapita Selekta Kedokteran, Jakarta, Grafika Utama Jaya.

Nasution, Barder Johan, 2008, Hukum Kesehatan, Pertanggungjawaban Dokter, Jakarta, Rineka Cipta.

Purnomo, Bambang 2003, Hukum Kesehatan, Program Pendidikan Pascasarjana, Fakultas Kedokteran, Universitas Gajah Mada, Jogjakarta, Aditya Media.

Subekti, R. dan R. Tjitrosudibio, 2002, Kitab Undang-Undang Hukum Perdata, Jakarta, PT Pradnya Paramita.

Sukanto, Soerjono Segi-segi Hukum, Hak dan Kewajiban Pasien dalam Kerangka Hukum Kesehatan, Jakarta, Rineka Cipta.

\section{Perundang-undangan}

Undang-Undang Republik Indonesia Nomor 29 Tahun 2004 Tentang Praktik Kedokteran

Undang-Undang Republik Indonesia Nomor 36 Tahun 2009 Tentang Kesehatan 